\title{
A dimensão religiosa na obra Quarto de despejo
}

\author{
Josias da Costa Júnior \\ Universidade do Estado do Pará - UEPA
}

\section{Resumo}

Este artigo insere-se no quadro da interface entre literatura e religião. Analisa a obra Quarto de despejo, da escritora Carolina Maria de Jesus, destacando a dimensão religiosa nela presente. Tem como ponto de partida e referência teórica a Teologia da Cultura, de Paul Tillich, notadamente sua compreensão de religião como preocupação suprema e a noção de demônico, para evidenciar o caráter ambíguo da religião e das formas culturais. Oferecendo destaque aos recursos linguísticos que a autora utiliza a fim de reconstruir textualmente sua vida de precariedade e seus sentimentos, o objetivo deste texto é apontar novas chaves hermenêuticas para a compreensão da obra literária.

Palavras-chave: religião e cultura; Carolina Maria de Jesus; hermenêutica.

\section{The Religion in the book Quarto de despejo}

\begin{abstract}
This article is part of the interface between literature and religion. It analyzes the work Room of eviction, by the writer Carolina Maria de Jesus, highlighting the religious dimension present in it. Its starting point and theoretical reference is Paul Tillich's Theology of Culture, noddedly his understanding of religion as a ultimate concern and the notion of demonic, to highlight the ambiguous character of religion and cultural forms. Offering emphasis to the linguistic resources that the author uses in order to textually reconstruct her life of precariousness and her feelings, the aim of this text is to point out new hermeneutic keys for the understanding of literary work.
\end{abstract}

Keywords: religion and culture; Carolina Maria de Jesus; hermeneutic.

\section{La Dimensión religiosa en el Quarto de despejo}

\section{Resumen}

Este artículo es parte de la interfaz entre la literatura y la religión. Analiza la obra Sala de desalojo, de la escritora Carolina María de Jesús, destacando la dimensión religiosa presente en ella. Su punto de partida y referencia teórica es la Teología de la Cultura de Paul Tillich, con la cabeza su comprensión de la religión como una preocupación 
suprema y la noción de demoníaca, para resaltar el carácter ambiguo de la religión y las formas culturales. Haciendo hincapié en los recursos linguísticos que la autora utiliza para reconstruir textualmente su vida de precariedad y sus sentimientos, el objetivo de este texto es señalar nuevas claves hermenéuticas para la comprensión de la obra literaria.

Palavras clave: Religión y cultura; Carolina Maria de Jesus; hermenéutica

\section{Primeiras considerações}

O livro Quarto de despejo: diário de uma favelada está comemorando este ano 60 anos desde sua primeira publicação. Lançado em agosto de 1960, o texto escrito por Carolina Maria de Jesus alcançou estrondoso e merecido sucesso, que se estendeu para além das fronteiras do Brasil. Ele foi traduzido para outros 17 idiomas e distribuído em 49 países, tornando-se uma importante obra da literatura brasileira contemporânea. A divulgação do livro, com ênfase em temas sociais, o reduziu a uma literatura de protesto, com sua denúncia social sendo o ponto forte da obra (cf. CORONEL, 2014, p. 274). A década de 1960 era de grande efervescência política e social e isso favorecia uma leitura com esse corte teórico. Porém, reduzir o livro ao nível de um documento fiel à realidade da favela, um "testemunho real", como apresentou o editor na orelha da primeira edição, é demasiado estreito. Um dos problemas desse reducionismo é a perda da complexidade de questões que tem a narrativa da autora, que são criadas pelo uso dos recursos da linguagem.

Quarto de despejo é qualificada como obra autobiográfica, na medida em que a própria escritora se faz sua personagem principal que interage com outras personagens e também é a narradora. Como veremos mais adiante, o texto traz muitos elementos de criação e de representação literárias que emprestam força e são muito significativos para sua compreensão. Com isso, não podemos reduzir o texto de Carolina Maria de Jesus a mero relato da realidade. Na obra O pacto autobiográfico, Philippe Lejeune além de dar o status de a autobiografia pertencer ao sistema literário vai lhe conferir valor estético e o fato de ser uma narrativa já seria a motivação para ser analisada, segundo ele. Trata-se, assim, de uma prosa que uma pessoa concreta narra sobre sua própria existência (LEJEUNE, 2008, p. 14). Basicamente o que vai definir essa forma de escrever e caracterizar o gênero autobiográfico é a identidade entre autor/autora, narrador/narradora e personagem, um "pacto autobiográfico", conforme qualifica Lejeune.

Neste artigo, Quarto de despejo será tomado como texto literário contemporâneo tanto quanto são outros textos da nossa literatura, como Guimarães Rosa, Clarice Lispector, Adélia Prado, isto é, não limitado a meros 
enquadramentos que o restringe a gêneros específicos de testemunhos, por exemplo. Isso não significa que análises a partir desses aspectos sejam sem importância ou de menor expressão, mas apenas queremos enfatizar a voz autoral de Carolina de Jesus, que é escritora e produz literatura. $\mathrm{O}$ fato de ela ser mulher, preta, da favela não a limita a uma única temática, assim como não a condiciona a tratar apenas daquilo que se espera que ela deve e pode fazer, ou seja, somente falar do único assunto que supostamente conhecia: a favela, a miséria, a fome (CORONEL, 2014, p. 275). Portanto, é para além desses estigmas e reducionismos que devemos tratar a obra de Carolina Maria de Jesus, sem ignorar os variados interesses e temas que são abordados em sua narrativa, entre os quais aqueles que foram fartamente explorados para a promoção de sua obra.

Para Antonio Candido, a literatura é um direito fundamental, pois ela tem papel humanizador profundo. Ele defende, ainda, a importância das mais diversas formas de expressão literária e não apenas um tipo de literatura. No contexto de sua insistência de como vê o papel da literatura, ele escreve: "a eficácia humana é função da eficácia estética e, portanto, o que na literatura age como força humanizadora é a própria literatura, ou seja, a capacidade de criar formas pertinentes" (CANDIDO, 1995). Assim, Quarto de despejo é um bom exemplo daquilo que foi defendido por Candido, isto é, a literatura é fundamental na construção de si mesmo e de mundo. Por isso, é preciso ir além do olhar que reduz a escrita de Carolina Maria de Jesus a mero registro da realidade porque sua obra contém elementos de representação e criação literárias de si e daquilo que a circunda. Nesse sentido, seu texto não é apenas a narrativa de uma mulher preta, pobre, favelada, mãe solteira por três vezes e pouco escolarizada, pois mostra o talento de uma escritora que reconstrói textualmente o sofrimento diário e infindável que ela, assim como outras pessoas, vive na favela do Canindé, na cidade de São Paulo, e que tem a experiência da fome no centro dessa narrativa.

Neste trabalho, o texto Quarto de despejo, de Carolina Maria de Jesus, será tratado como uma produção cultural estética, ou seja, como um texto da literatura brasileira contemporânea, e a partir daí a proposta é analisar essa obra mergulhando em seu subterrâneo espiritual abrindo assim a possibilidade de diálogo entre estudos literários e estudos de religião, especificamente com a Teologia da Cultura de Paul Tillich. Considerando que o texto se constitui a partir da elaboração do sujeito discursivo, isto é, de quem enuncia o discurso, e que são plurais na medida em que são elaborados na discursividade 
(CARRIJO, 2018, p. 156), é possível falar, por exemplo, do sujeito discursivo religioso e/ou que tem discurso religioso. A abordagem do texto de Carolina de Jesus não se dará exclusivamente a partir das suas referências diretas feitas à religião, que seria perfeitamente possível. Todavia, como mostraremos mais adiante, o tema da obra, mesmo não sendo religioso, apresenta elementos que permitem dizer que ela está impregnada do poder religioso. Assim, partiremos da ideia fundamental segundo a qual não há manifestação cultural desprovida de uma preocupação última, conforme o pressuposto da teologia da cultura de Tillich.

Os contrastes existentes na narrativa de Carolina Maria de Jesus podem nos remeter para aquilo que Tillich fala sobre o absoluto, que pode estar presente ou ausente "em qualquer situação" (TILLICH, 2009, p. 118). As situações narradas em Quarto de despejo revelam um quadro de absurdo sofrimento que se objetiva na luta diária contra fome, fazendo com que a personagem tenha que, a cada dia, se submeter às mais árduas atividades de trabalho (catar papel no lixo, ferro e tudo que encontrar pela frente) que possam render-lhe dinheiro suficiente para alimentar a si mesma e a seus três filhos.

Abordaremos, num primeiro momento, alguns aspectos da teologia da cultura, de Paul Tillich, a partir da sua compreensão sobre religião como preocupação suprema e o conceito de demônico. Mais adiante, arriscaremos uma leitura do livro Quarto de despejo, tendo como ponto de partida esses conceitos tillichianos.

\section{Religião como preocupação suprema e a noção de demônico: considerações sobre a Teologia da Cultura}

O que o filósofo e teólogo germano-americano Paul Tillich defendia como uma Teologia da Cultura necessariamente nos faz admitir a tese segundo a qual a religião se manifesta em toda produção cultural humana. Para ele, a religião é definida no ato de o ser humano ser tomado por uma preocupação incondicional. O Incondicional sempre está ativo e a espera de ser descoberto para além dos limitantes e limitados muros da comunidade eclesial. Em uma nota de rodapé do livro A Era Protestante, Tillich (1992, 63) faz o seguinte esclarecimento:

O termo 'incondicional' [...] refere-se ao elemento presente em qualquer experiência religiosa responsável pelo caráter religioso dessa experiência. Todos 
os símbolos religiosos do divino expressam certa afirmação incondicional. É o que se pode verificar de maneira muito acentuada no mandamento: 'Amarás ao Senhor teu Deus com todo o teu coração, com toda a tua alma e com toda a tua mente'. Não se admite, nesse caso, nenhum amor parcial, restrito ou condicional a Deus. O termo 'incondicionado', ou a substantivação 'O Incondicional' é a abstração de ditos como o citado, que aparecem com frequência na Bíblia e na literatura religiosa clássica. Não se trata de um ser, mas de uma qualidade. Caracteriza nossa preocupação suprema e, consequentemente, incondicional, não importando se a chamarmos de 'Deus', de 'ser', do 'bem', da 'verdade' ou de qualquer outro nome. [...] Trata-se da qualidade experimentada no encontro com a realidade, por exemplo, no caráter incondicional da voz da consciência, tão lógica quanto moral.

Pelo fato de o mistério sempre se fazer presente, a tarefa da teologia da cultura consiste em trazê-lo à tona, como um ato de retirar o manto que o encobre, e identificar o conteúdo religioso ou substância religiosa discriminável em todas as dimensões da cultura, mesmo no mais improvável escombro que se possa imaginar. Nesse sentido, sua teologia foi elaborada em diálogo e confronto constantes com movimentos filosóficos, teológicos, científicos, políticos e artísticos do século XX, com o fito de perceber a dimensão religiosa ali presente. Assim o seu método da correlação foi criado e o tema da relação entre religião e cultura, que, segundo ele, sempre ocupou o palco central de suas preocupações (TILLICH, 2009, p. 33), é o fio que conduz toda a sua reflexão teológica, que se propõe a enfrentar basicamente duas questões: a redefinição do conceito de religião e mostrar a relação de interdependência entre religião e cultura.

A religião é a dimensão da profundidade de todas as funções e atividades da vida humana. Tillich mostra que no curso da história a religião esteve em diferentes "funções espirituais" - cultura - (TILLICH, 2009, p. 42), para ser rejeitada posteriormente, e percebe o processo de rejeição pelo qual foi submetida no curso do desenvolvimento histórico. Tillich (2009, p. 42-44) descreve as oscilações da religião por diferentes funções espirituais até chegar à sua rejeição.

Primeiro, a religião teve função na moral e foi bem acolhida por ela, pois a ética é muito próxima da dimensão religiosa, mas a religião foi deixada de lado como desnecessária ou perigosa para a moral. Depois, a religião passou a ser atraída pela função cognitiva, sendo um modo particular de conhecimento: imaginação mitológica ou intuição mística. Porém, o sucesso 
das conquistas científicas fez com que essa relação fosse afetada e a ciência proclamou sua independência da religião, que ficou sem lugar na vida espiritual humana (cultura).

Quando deixou de ter lugar na vida cultural, a religião buscou outra função e se voltou para a dimensão estética. Os domínios da criatividade artística pareciam, segundo os filósofos da religião, adequados para ela e o meio artístico afirmou que arte é religião. Todavia, nesse momento a religião teve um pouco de resistência, questionando certa irrealidade mesmo nas maiores obras de arte. A religião, assim, relembrou suas relações anteriores com a moral e a ciência e resistiu à tentação de se diluir na arte.

Finalmente, a religião se voltou para o sentimento, algo que acompanha todas as atividades e funções da vida espiritual. Religião é sentimento e isso agradou aqueles que quiseram libertar a moral e o conhecimento de interferência religiosa. $\mathrm{Na}$ avaliação de Tillich, ser jogada e reduzida ao âmbito da simples subjetividade sentimental desprovido de um objeto definido e sem conteúdo supremo, significa a morte da religião.

Assim, a religião, sem lugar para habitar, percebe não precisar de ficar exclusivamente em nenhum deles, pois já possuía lugar próprio em todos os lugares, sobretudo nas profundezas da cultura. Por isso ele defende: "a religião é a dimensão da profundidade em todas elas. É o aspecto dessa profundidade na totalidade do espírito humano" (TILLICH, 2009, p. 44). Profundidade, segundo ele, significa dizer que o religioso volta-se para os elementos supremos da cultura. Nesse sentido, a religião é "preocupação suprema" (ultimate concern) que se manifesta em todas as funções espirituais e na esfera moral.

Essa concepção de religião permite-nos compreendê-la para além da expressão de ritos, devoção e crenças e também a descortinar um horizonte de compreensão de religião que aponta para o estado de ser tomado por uma preocupação suprema, Incondicional, que abala o ser humano. Carlos Eduardo Calvani (1998, p. 95), que é um estudioso do pensamento de Tillich, assim escreve sobre o ultimate concern:

é uma preocupação suprema, a mais inquietante, a maior de todas, aquela que, comparada a todas as demais, as torna preliminares. Por isso, toda criação cultural tem necessariamente um significado religioso, pois nasce de uma posição assumida diante do Incondicional, ainda que tal posicionamento seja de indiferença, rejeição ou niilismo. Por isso, é perfeitamente admissível que um entalhe em madeira, em formas geométricas esculpidas em gesso ou 
palavras articuladas de acordo com certa métrica e certo ritmo expressem algo de religioso, principalmente se o estilo for adequado. A dimensão religiosa de uma obra de arte, portanto, deve ser buscada não no resultado final, mas no impulso originário que vem do fundamento da cultura.

Esse é o campo de possibilidade para a relação entre religião e cultura em geral e religião e arte - de modo um pouco mais específico - em seus mais diferentes modos de expressão, que parte de um conceito em que a religião não está exclusivamente ligada à vivência espiritual organizada institucionalmente.

O professor Etienne Higuet, que estuda o pensamento de Tillich desde os anos 1960, ao destacar as principais linhas da teologia da cultura do teólogo protestante, chama a atenção para o fato de que ele oferece uma definição sobre a cultura que se resume na tarefa de decifrar o seu estilo partindo da análise das formas culturais. Concretamente a noção tillichiana de cultura tem a opção preferencial para as áreas "superiores" da produção humana (HIGUET, 2019, p. 14), manifestações artísticas mais elitizadas, que não nasceram ou se reproduziram em ambientes populares. ${ }^{1}$ Nesse sentido, inicialmente a sua noção de cultura apresenta seus limites, por considerar basicamente um processo que aponta para o refinamento do comportamento do ser humano e de suas grandes realizações em campos diversos como a ciência, a organização social, a arte, a religião. Esse choque da noção tillichiana de cultura frente à noção atual predominante nas ciências sociais indica limites e pode gerar o questionamento sobre o alcance de sua teologia da cultura para análise de expressões culturais artísticas que não se enquadram nos padrões exigidos por ele, como é o caso das expressões de artes populares. ${ }^{2}$

Voltando ao teólogo, é importante dizer que ele se mantém numa linha de compreensão em que a leitura do estilo de uma cultura é determinante para se atingir a preocupação suprema, a substância religiosa de uma produção cultural. Tillich (2009, p. 115) esclarece sobre a questão do estilo, quando escreve:

\footnotetext{
1 Em seu livro Teologia e MPB, Calvani (1998, p. 69) analisa criticamente essa inclinação tillichiana por manifestações artísticas mais ligadas à elite e um distanciamento dessas manifestações mais populares. A sua formação burguesa e eurocêntrica e sua proximidade com a Escola de Frankfurt, segundo ele, são as razões prováveis para que Tillich tenha assumido esse posicionamento.

2 Isto exigiria uma discussão mais ampla e cuidadosa, mas que superam as pretensões e os limites deste texto. O teórico britânico Terry Eagleton, por exemplo, em A ideia de cultura (2011), discute essa noção de cultura tentando superar tanto as definições do campo antropológico quanto da estética.
} 
o problema do estilo consiste em se achar que coisa é essa que certas obras têm em comum. Que indicam? Derivando minha resposta das muitas análises de estilo, chego à conclusão de que cada estilo indica a autointerpretação do ser humano em resposta à questão do significado último da vida. Não importa qual seja o tema escolhido pelo artista nem a qualidade da forma (que pode ser fraca ou forte), ele sempre demonstrará em seu estilo sua preocupação suprema, que será a mesma de seu grupo e de seu tempo.

O que Tillich escreve acima está no contexto de uma discussão mais ampla sobre a tríade dos elementos contidos nas obras de arte, que são: tema, forma e estilo. Basicamente ele explica que o tema, em termos potenciais, é tudo aquilo que a mente humana pode receber nas imagens sensoriais. Ele é algo que não está limitado por qualidades de bom ou mau, feio ou belo, partido ou inteiro, desumano e humano e também demoníaco ou divino. $\mathrm{O}$ tema - o assunto - é, nesse sentido, de livre escolha do autor da obra e pode ser variado. O segundo elemento é a forma, que faz parte dos elementos estruturais do ser e devem ser entendidos como aquilo que faz com que a criação cultural seja o que ela realmente deve ser. Nesse sentido, o que determina se uma criação cultural é filosófica, literária ou de outra natureza é a forma, tanto quanto é ela que vai determinar o que é a criação artística, isto é, palavras, cores, som. Contudo, o que qualifica a forma é o terceiro elemento dessa tríade, que é o estilo. Assim, é a partir das formas que existem as criações em geral, mas é o estilo que nos permite ver o que elas têm em comum (TILLICH, 2009, p. 114-116).

O estilo é a senha que abre as portas a fim de possibilitar a percepção da qualidade religiosa de uma expressão cultural artística, ou seja, através dele é que se descobre a substância religiosa de uma cultura. Assim, ao se falar especificamente de uma obra de arte, o estilo é algo que se sobrepõe a uma decisão individual, pessoal. Com isso, a condição social, biográfica, econômica, psicológica do artista não são determinantes, embora importantes, porque mesmo que essas situações exerçam influência, elas não são capazes de abrigar o caráter religioso da obra.

A partir da linha de compreensão acima esboçada, podemos dizer que o fato de uma obra de arte se remeter a Deus ou a outros aspectos religiosos não significa que ela seja religiosa. Por outro lado, mesmo que uma produção artística não apresente um tema religioso ela pode estar eivada do poder religioso porque não é o tema que vai caracterizar a arte como religiosa, mas o estilo e o conteúdo substancial, pois, conforme Tillich esclarece, o 
tema pode ser escolhido, assim como é possível buscar a forma. Contudo, a substância vai além, pois é "o solo a partir do qual ela cresce [...] Ela está inconscientemente presente numa cultura, num grupo e num indivíduo, dando a paixão e o poder diretivo àquele que cria, bem como o significado e o poder de sentido às suas criações" (TILLICH, 1987, p. 431).

Outro aspecto importante a ser considerado na teologia da cultura desenvolvida por Tillich é a noção de demônico. Embora ele atravesse sua obra maior, que é a Teologia Sistemática, o conceito é anterior a essa fase em que o filósofo e teólogo está estabelecido em terras americanas, pois ele se articula e já se firma na obra Filosofia da religião, de 1925. Nesta, o conceito é usado a fim de se contrapor ao divino e os dois estão inseridos na esfera do sagrado, conforme escreve: "o demônico é o Santo (ou o sagrado) precedido por um sinal de menos". Trata-se de uma espécie de sagrado negativo, mas que ainda permanece como sagrado, pois tem a mesma origem. Então qual é a diferença entre o demônico e o sagrado? Tillich (1973, p.74) assim responde a essa questão:

a diferença, entretanto, é esta: a graça atravessa a forma reconhecendo-a, aumentando-a, ao mesmo tempo que afirmando a forma incondicional. $\mathrm{O}$ demônico possui todas as formas de expressão que subsistem no sagrado, mas as possui com a marca da oposição à forma incondicional e com a intenção destrutiva. A santa negatividade do abismo se converte em negatividade demoníaca mediante a perda da forma incondicional.

Nessa concepção, sagrado e profano são como rios que provêm da mesma nascente. Nesse caso, da mesma fonte onde provém a graça também flui o abismo. Eis aí a compreensão religiosa dialetizada por Tillich e, assim, a ambiguidade do sagrado é por ele simbolizada por meio do conceito de demônico, que carrega a marca da negatividade do incondicional e das forças destrutivas, pessoal e social.

Convém esclarecer que há uma necessária distinção entre o conceito de demônico e os mitos que o originam, mesmo que se possa reconhecer vestígios mitológicos das religiões no conceito, pois os mitos também expressam esse abismo. Assim, com o conceito de demônico, Tillich não se remete a entidades espirituais, seres espirituais, os chamados demônios, que podem possuir um corpo humano, mas sabe que o que ele traduz em conceito vem do imaginário mitológico das religiões (CALVANI, 1998, p. 59).

O demônico é essencialmente religioso, por ter preocupações marcadamente incondicionais. O conceito expressa "o poder estrutural e, 
portanto, inevitável do mal". Isso é muito mais do que apenas reconhecer o mal como decorrente de atitudes individuais, de escolha livre e soberana de um indivíduo guiado por sua consciência (aspectos esses que podem ser ajustados ou corrigidos através de processos educacionais religiosos), mas do reconhecimento de uma "estrutura do mal" (TILLICH, 1992, p. 21-22). Pelo uso do termo citado fica clara a sua preocupação em mostrar que esse conceito perpassa as formas culturais, sem que nelas se encerre, e assim o demônico alcança também as dimensões sociais.

Dessa forma, o demônico, para além de decisão pessoal e com caráter estrutural do mal, é o conceito que melhor expressa a ambiguidade que ocorre em todo progresso de uma sociedade. É significativo o fato de o demônico estar presente em diversas produções artísticas como um conceito que em geral está relacionado à destruição da forma, como algo que mostra a existência de uma realidade antagônica à forma. Assim, corpos distorcidos e com exageros de algumas partes do corpo humano que as tornam desproporcionais, expressões faciais de pavor ou horror, podem ser demonstrações dessa existência contrária às formas comuns, que apontam para a existência dessa realidade demônica. Tillich entendia que era tarefa da teologia da cultura dizer algo sobre a estrutura do mal na sociedade de seu tempo.

Os aspectos relacionados ao conceito de demônico são paradoxalmente relacionados à outra extremidade da polarização, que é o divino. Isso porque ele pertence, como já vimos, à esfera do sagrado. Nenhum outro conceito para a interpretação da história foi mais utilizado, seja na literatura secular ou religiosa, do que o demônico. Tillich vai afirmar que essa estrutura do mal, que é carregada de intenções destruidoras, capaz de "limitar a liberdade dos indivíduos", somente "poderá ser superada pelo seu oposto, que é a estrutura divina que chamamos de estrutura ou 'Gestalt' da graça” (TILLICH, 1992, p. 22).

Tillich toma a manifestação do demônico na personalidade como um prelúdio de suas reflexões e aplicação ao nível social. Assim como as estruturas dos indivíduos, também a sociedade e a cultura são alvos de uma posse demoníaca. As diferentes esferas como a economia, através do capitalismo e seus mecanismos (livre mercado, autorregulação) expressam a força da atuação demônica na economia autônoma, que tem como resultado final da autonomia do mercado capitalista a destruição das pessoas impiedosa e esmagadoramente. Na esfera política, o nacionalismo nazifascista é, sem dúvida, a expressão mais clara e evidente dessa posse demônica. Uma 
particularidade assombrosa que acentua a trágica situação da época é a percepção de que a força demônica nacional estava submissa ao capitalismo, indicando a união entre economia e política a partir de bases destrutivas (CALVANI, 1998, p. 61). De igual modo, pode-se pensar em outros contextos, como o brasileiro escravocrata ou do seu processo modernizador da metade do século XX, conforme veremos mais adiante na narrativa de Carolina Maria de Jesus, e ainda na atualidade com a manutenção das desigualdades sociais.

Para Tillich, era necessário tomar consciência sobre o perigo concreto da situação de sua época e as forças demônicas precisavam ser enfrentadas. Esse enfrentamento não devia ser com base na confiança no progresso, mas devia considerar que o demônico é de caráter estrutural (a estrutura do mal) e deve ser vencido pela estrutura divina, que é a estrutura ou Gestalt da graça (TILLICH, 1992, p. 22). Essas são ideias que prenunciam o seu engajamento no socialismo religioso, sendo este movimento de prática política da teologia da cultura.

De fato, para Tillich, há uma necessidade de se dizer algo sobre as forças destrutivas na sociedade e essa é uma das tarefas que se apresenta à teologia da cultura. O demônico com sua ambiguidade comporta tanto um elemento de criação quanto de destruição, fundamento e abismo que se originam de uma única raiz. Esse princípio da ambiguidade do demônico, que provém da ambiguidade do próprio sagrado, permite pensar o conceito como um movimento dinâmico, de criação e destruição, que subjaz as ambiguidades da vida e que demarca um aspecto fundamental para a compreensão tanto da religião quanto da cultura.

O conceito de demônico, como vimos, apresenta-se com grande potencial interpretativo para a análise da obra Quarto de despejo, mesmo que o próprio Tillich tenha investido mais na análise de outras formas artísticas, como as artes plásticas, e não tenha dedicado textos seus específicos para analisar obras de literatura. A metáfora da religião como dimensão de profundidade indica para o que é mais fundamental e sem que haja algo mais importante. Assim, a religião é afirmada como substância que está em toda a cultura. Dessa forma, a teologia da cultura é o ponto de partida para a análise do texto de Carolina Maria de Jesus.

\section{O poder religioso da literatura em Quarto de despejo: transcendência, profetismo, contemplação}

A tarefa que nos cabe agora é enfrentar mais diretamente o texto de Carolina Maria de Jesus e arriscar uma leitura tomando como referência a 
teologia da cultura. Isso significa antes de tudo reconhecer o texto Quarto de despejo como uma verdadeira expressão artística, de uma escritora, uma manifestação cultural que expressa uma visão de mundo. Como já dissemos neste texto, o fato de a literatura ser fundamental na construção de si mesmo e de mundo impõe-se a necessidade de ter de ir além de uma interpretação que reduz a escrita de Carolina Maria de Jesus a mero registro da realidade, pois o texto enquanto expressão artística transcende a objetividade e vai além porque transcende também a subjetividade. Portanto, sua obra contém elementos de representação e criação literárias de si e daquilo que a circunda.

As narrativas de Carolina Maria de Jesus revelam os muitos contrastes existentes que se expressam entre a beleza do mundo e as injustiças que nele abunda. Revelam ainda a capacidade e o seu talento na reconstrução textual dessas dificuldades enfrentadas na favela do Canindé. O livro aborda vários aspectos da sua vida, mas a experiência da fome é o grande tema do texto que se mostra, muitas vezes, duplo: de pão e de arte.

Não tomei café, ia andando meio tonta. A tontura da fome é pior do que a do alcool. A tontura do alcool nos impele a cantar. Mas a da fome nos faz tremer. Percebi que é horrível ter só ar dentro do estômago. Comecei a sentir a boca amarga. Pensei: já não basta as amarguras da vida? Parece que quando eu nasci o destino marcou-me para passar fome. Catei um saco de papel. Quando eu penetrei na rua Paulino Guimarães, uma senhora me deu uns jornais. Eram limpos, eu deixei e fui para o deposito. Ia catando tudo que encontrava. Ferro, lata, carvão, tudo serve para o favelado. O Leon pegou o papel, recibi seis cruzeiros. Pensei em guardar para comprar feijão. Mas vi que não podia porque o meu estômago reclamava e torturava-me. Resolvi tomar uma média e comprar um pão. Que efeito surpreendente faz a comida no nosso organismo! Eu que antes de comer via o céu, as árvores, as aves, tudo amarelo, depois que comi, tudo normalizou-se aos meus olhos. A comida no estômago é como combustível nas máquinas. Passei a trabalhar mais depressa. Meu corpo deixou de pesar. [...] Eu tinha a impressão que eu deslizava no espaço. Comecei a sorrir como se eu estivesse presenciando um lindo espetáculo. E haverá espetáculo mais lindo do que ter o que comer? Parece que eu estava comendo pela primeira vez na minha vida (JESUS, 2001, p. 39-40).

Tillich (2009, p. 87-88) argumenta que na sociedade industrial, a ilusão humana de ser mestre do mundo e de si mesmo se choca com a realidade de ser apenas parte de uma engrenagem e que a adaptação é o que se exige para não ser por ela esmagado, transformando o ser humano em meios sem finalidades. As experiências de vazio surgem dessa desumanização, falta de 
sentido e alienação. Diante disso, a construção de mecanismos de defesa e de afastamento da realidade podem ser alternativas, que envolve reprimir a busca de sentido. Contudo, há aquelas pessoas que assumem a angústia e a falta de sentido expressando a situação humana através de produção cultural artística, sejam elas arte visual, poesia, música, literatura. São essas expressões que fazem o enfrentamento com o "não-ser" e o reconstrói criativamente. Nesse sentido, ele entende que com essa chave, a cultura contemporânea "pode ser entendida como revelação da situação humana".

No livro Coragem de ser, Tillich (1976, p. 111) remete-se a algumas obras literárias que, segundo ele, manifestam características existencialistas, pois elas carregam, como ele escreve, "a coragem de enfrentar as coisas como elas são, e expressar a ansiedade da insignificação. É coragem criadora que aparece nas expressões criadoras do desespero". Nesse caso, é coragem de enfrentar sua finitude, aquilo que ele chama de tomar sobre si "a aceitação da insignificação" (1976, p. 112), citando como exemplos os romances $O$ processo (1925), de Kafka, e O estrangeiro (1942), de Camus.

Algumas dessas características encontramos no texto de Carolina Maria de Jesus, na medida em que se faz personagem de uma história ambientada no contexto da emergente sociedade industrial onde é um mero objeto entre outros, sem significação por si mesma. São os recursos da linguagem, usados para descrever sua rotina de sofrimento, que possibilitam à autora a criação de uma narrativa incisiva e comovente. Na cena acima citada, por exemplo, a boca amarga provocada pela fome a leva enfrentar o fato de que sua vida também é marcada por amarguras e, assim, questionar o sentido de uma existência destinada a passar fome. Essa situação extrema é representada pela cor amarela: céu, aves, árvores... tudo ficou amarelado pela fome aguda. Contudo, depois de se alimentar tudo voltou ao normal, isto é, todas coisas que se tornaram amarelas por causa da fome, deixaram de ser.

O título "Quarto de despejo" é uma imagem muito significativa, com capacidade de expressar sinteticamente e com muita força o drama de viver à margem de um processo de modernização que, através de um projeto políticoeconômico conservador, ${ }^{3}$ uma "estrutura do mal", em linguagem tillichiana, exclui impiedosa e cruelmente uma parcela da população, condenando-a à insignificância. Esse é o processo de modernização, que estava em curso na época de sua escrita, e suas contradições, suas ambiguidades. Assim ela

\footnotetext{
A narrativa se remete ao contexto histórico marcado pelo vigor desenvolvimentista, especialmente a segunda metade da década e 1950, "marcada pelo avanço do processo de industrialização brasileiro" (CAPUTO; MELO, 2009, p. 514).
} 
reconstrói textualmente sua visão sobre esse progresso e o sentimento de viver à margem dele, excluída:

quando estou na cidade tenho a impressão que estou na sala de visita com seus lustres de cristais, seus tapetes de viludos, almofadas de sitim. E quando estou na favela tenho a impressão que sou um objeto fora de uso, digno de estar num quarto de despejo (JESUS, 2001, p. 33).

A narrativa enfatiza a contradição provocada pelo modelo de desenvolvimento adotado no país, que não promoveu mudanças estruturais capazes de alterar a situação de pessoas pobres: o progresso e o enriquecimento da cidade são representados pela "sala de visita" (que foi beneficiada com os grandes investimentos) e o "quarto de despejo" abriga quem não foi alcançado positivamente pelo progresso, os marginalizados, como as pessoas negras e com pouca escolarização formal. Portanto, ela experimenta o sentimento de ser um mero objeto, desnecessário e descartável, entre tantos outros objetos descartáveis.

A consciência da insignificância e do abandono, por se ver sem direitos, vivendo apenas dos restos e das sobras indicam esse processo desumanizador, consequência da marginalização social, que é a da vida na favela, e assim escreve: "eu também sou favelada. Sou rebotalho. Estou no quarto de despejo, e o que está no quarto de despejo ou queima-se ou joga-se no lixo" (JESUS, 2001, p. 33). Um momento marcante desse estado de desespero, angústia e insignificância, que lhe subtrai o "hábito de sorrir", é quando ela reflete com ironia sobre sua condição contraditória de sentir-se escravizada, como diz, no "dia da Abolição. Dia que comemoramos a libertação dos escravos". Sente-se escravizada vivendo exatamente no período da industrialização e da década desenvolvimentista do Brasil: "a Vera começou a pedir comida. E eu não tinha. Era a reprise do espetaculo [...] E assim no dia 13 de maio de 1958 eu lutava contra a escravatura atual - a fome!" (p. 27). O drama da cena descrita, como ela evidencia, era vivido diariamente e não havia nenhuma perspectiva de que o desfecho seria feliz.

A reelaboração textual das suas angústias, através de estratégias no uso de palavras, confere força dramática à narrativa. Em algumas situações, ela utiliza o humor para descrever uma cena de forte carga dramática. É surpreendente por ser uma situação de extrema aflição, mas trata-se de um recurso usado por ela para reconstruir textualmente a dor e enfrentar tamanha escassez: "cheguei na favela os meus meninos estavam roendo um pedaço de pão duro. Pensei: 
para comer estes pães era preciso que eles tivessem dentes elétricos” (p. 36). É angustiante ver crianças roer pães duros por falta de outro alimento, mas também impressiona a força criativa da narrativa de Carolina Maria de Jesus para descrever a cena e enfrentar a dura situação e não sucumbir diante dela.

Através dos diversos recursos da língua, dos quais ela se vale, a narrativa permite que os leitores tenham acesso ao outro lado do processo de modernização em curso no Brasil dos anos 1950, cujo sistema conservador excluiu o acesso de pessoas como Carolina Maria de Jesus: mulher negra, migrante, com pouca escolarização. Bom exemplo desse uso da língua para narrar sua vida precária e enfrentar suas duras consequências é outra cena em que novamente seus filhos se alimentam apenas com pão duro. Tomando o estado em que se encontrava o pão - duro - no momento em que chega em casa, ela promove uma ampliação do sentido a partir do estado em que se encontra o alimento, a fim de refletir a respeito de sua vida precária e de todas as pessoas que igualmente viviam naquelas condições desumanas: "os meninos come muito pão. Eles gostam de pão mole. Mas quando não tem eles comem pão duro. Duro é o pão que nós comemos. Dura é a cama que dormimos. Dura é a vida do favelado" (p. 37).

O mesmo recurso é utilizado para descrever sua infelicidade. Valendose de sua atividade de catadora de papel, ela reflete sobre o que seria seu destino: "depois fui catar lenha. Parece que eu vim ao mundo predestinada a catar. Só não cato a felicidade" (p. 72). Com a mesma estratégia ela desnuda a situação das pessoas negras nesse período do país: "quando puis a comida o João sorriu. Comeram e não aludiram a cor negra do feijão. Porque negra é a nossa vida. Negro é tudo que nos rodeia” (p. 39). São vários os momentos em que Carolina Maria de Jesus mostra como a precária situação das pessoas negras resultava de uma estrutura racista que as colocaram à margem da modernização no Brasil. ${ }^{4}$ Assim, o tema da negritude em Quarto de despejo está na base do problema da pobreza e da fome, que são evidenciados na narrativa.

\footnotetext{
4 Para Francisco Oliveira (2012, p. 3), o "jeitinho” é a opção preferencial que marca o modo como o brasileiro livra-se ou falsifica os problemas, como fizeram as classes dominantes para sustentar a coesão de um sistema superado e sua exploração, mesmo com mudanças nas forças produtivas do capitalismo no Brasil. Isso pode ser exemplificado no modo como a classe dominante agiu com relação aos ex-escravizados, negando-lhes a cidadania quando negaram-lhes o trabalho remunerado nas fazendas de café e, já pelos anos 1940 na indústria, quando optaram pela mão de obra europeia, sendo o fenômeno do trabalho informal uma das suas consequências: "surgia o trabalho informal, quer dizer, sem formas. O jeitão da classe dominante obrigou os dominados a se virarem por meio do jeitinho do trabalho ambulante, dos camelôs que vendem churrasquinho de gato como almoço, das empregadas domésticas" (OLIVEIRA, 2012, p. 4).
} 
A questão da negritude aparece diversas vezes e mostra principalmente o estigma que ela e outras pessoas sofrem por causa da cor da pele. Um dos principais estigmas presentes é o que relaciona a pessoa negra à miséria, à falta de escolaridade, à subalternidade. Contudo, Carolina Maria de Jesus reconstrói textualmente sua vida para além de estigmas e demonstra que, para ela, a leitura é algo tão essencial quanto um pedaço de pão, mesmo que isso seja um descompasso com sua condição socioeconômica: "tomei banho. Esquentei comida. Li um pouco. Não sei dormir sem ler. Gosto de manusear um livro. O livro é a melhor invenção do homem". A cena prossegue e mostra que ser escritora causava perplexidade em quem a via escrever, pois essa atividade não está associada a uma mulher negra e favelada: "- Nunca vi uma preta gostar tanto de livros como você" (p. 23), admirou-se um amigo. Com isso, ela contraria não apenas o seu amigo, mas toda a estrutura que sustenta e alimenta esse mesmo pensamento. Assim, mais do que uma simples distração, para ela, escrever é uma necessidade vital, pois através da escrita ela consegue transcender sua vida marcada pela exclusão social que gera dor, angústia, desespero.

Diante de tanto sofrimento testemunhado, vivenciado e reelaborado por meio de palavras, o texto de Carolina Maria de Jesus assume uma função profética que se apresenta como indignação, crítica sociopolítica, mas também de esperança. A indignação é com a vida precária que ela, seus filhos e os demais favelados levam. Críticas a políticos locais e nacionais e aos aparelhos do estado, que, em última instância, se traduzia também em crítica ao próprio projeto de desenvolvimento excludente desse período de industrialização no país e a esperança de que através da literatura ela vai mudar sua vida de precariedade.

Uma dessas recorrentes críticas sobre como agiam os políticos está na denúncia de que os seus interesses pelos problemas da favela só duram até que sejam eleitos:

os politicos só aparecem aqui nas epocas eleitoraes. O senhor Candido Sampaio quando era vereador em 1953 passava os domingos aqui na favela. Ele era tão agradável. Tomava nosso café, bebia nas nossas xicaras. Ele nos dirigia as suas frases de viludo. Brincava com nossas crianças. Deixou boas impressões por aqui e quando candidatou-se a deputado venceu. Mas na Camara dos Deputados não criou um progeto para beneficiar o favelado. Não nos visitou mais (JESUS, 2001, p. 28). 
Em outro momento, ela deixa claro que a precariedade com que ela e os demais marginalizados vivem está diretamente ligada à falta de ação política em âmbito estadual e nacional: "eu quando estou com fome quero matar o Janio, enforcar o Adhemar e queimar o Juscelino. As dificuldades corta o afeto do povo pelos políticos" (p. 29). Ela ratifica a crítica aos políticos afirmando que eles perceberam que abordar os graves problemas que assolam a população era o caminho para vencer nas urnas, mas essa aliança com os pobres logo é rompida. Nesse sentido, ela reconhece diante dos filhos que não se pode depositar fé em um político, como ela fez (referindo-se a Juscelino Kubitschek). Isso impulsiona sua reflexão sobre como as coisas se fragilizam no Brasil e escreve: "no nosso paiz tudo está enfraquecendo. O dinheiro é fraco. A democracia é fraca e os politicos fraquissimos" (p. 35). Mais adiante ela se reconhece como "poetisa" e completa: "o poeta enfrenta a morte quando vê seu povo oprimido" (p. 35). É flagrante aqui que sua visão acerca da postura de um poeta é igualada a de um profeta de Israel no mundo bíblico, com suas fortes críticas dirigidas à sociedade que não distribui justiça a todos.

Ao aprofundar a crítica política, ela observa que o Serviço Social não cumpre seu papel. Essa ideia se fortalece ao presenciar uma triste e degradante cena do jovem que come um pedaço de carne que encontra no lixo, pois não se alimentava há dois dias. Diante disso, ela escreve indignada: "isto não pode ser real num paiz fertil igual ao meu." Em seguida, ela direciona sua revolta: "revoltei contra o tal Serviço Social que diz ter sido criado para reajustar os desajustados, mas não toma conhecimento da existencia infausta dos marginais" (p. 36). Em outro momento diz com pesar que foi no Serviço Social que viu "as lagrimas deslisar dos olhos dos pobres", e prossegue: "como é pungente ver os dramas que ali se desenrola" (p. 37). Ela continua sua crítica e reconstrói com sua pena aquilo que entende sintetizar a raiz de muitos problemas que os pobres enfrentavam:

... mas eu já observei os nossos politicos. Para observá-los fui na Assembleia. A sucursal do Purgatorio, porque a matriz é a sede do Serviço Social, no palacio do Governo. Foi lá que eu vi ranger de dentes. Vi os pobres sair chorando. E as lagrimas dos pobres comove os poetas. Não comove os poetas de salão. Mas os poetas do lixo, os idealistas das favelas, um expectador que assiste e observa as trajedias que os politicos representam em relação ao povo (JESUS, 2001, p. 47). 
Essa reconstrução textual, que avalia a situação de precarização social, lança mão de metáforas recolhidas da tradição religiosa como recurso linguístico para intensificar sua forte crítica aos políticos e às instâncias governamentais. Assim, a narrativa apresenta os locais de onde se originam os sofrimentos dos pobres. Eis, uma vez mais, a ambiguidade do progresso e das formas culturais, pois o serviço social, de caráter sociopolítico, deveria ser o braço do governo para intervir em aspectos como a desigualdade oriunda dos interesses conflitantes (inclusão e socialização da produção versus concentração privada dos frutos do trabalho). No entanto, ocorre precisamente o contrário, segundo revela a narrativa, isto é, de onde deveria vir a esperança vem a desilusão.

Ao reconstruir em texto a origem da dor e do sofrimento dos pobres presentes nessas instâncias - Assembleia, Serviço Social e Governo -, a autora nos oferece a visão dessas instituições com um sinal de menos, ou seja, são elas a negatividade daquilo que originalmente deveriam ser. Assim, podemos dizer, a partir de Tillich, que essa estrutura do estado, conforme a narrativa de Carolina Maria de Jesus, é uma expressão da potência demônica na política. Tal como o demônico, que, como vimos, comporta tanto um elemento criador quanto destruidor, também a política, que deveria proporcionar bem-estar, uma vez comprometida com um projeto conservador e excludente de progresso, revela-se particularmente trágica na medida em que sucumbe ao poder do capitalismo, pois este é a expressão da potência demônica da economia.

Outro aspecto da cena narrada é que ela mais uma vez expressa a figura de poeta como a de um profeta. Nesse sentido, é importante destacar que denunciar os problemas sociais e lutar por uma sociedade mais justa eram temas recorrentes e de grande força na mensagem profética (cf. SICRE, 1998, p. 357). Esse é o caso de Amós, que se destaca na luta pela justiça e, por isso, pode ser chamado de o "profeta da justiça" (BONORA, 1983, p. 23). Também Isaías, que denunciou uma sociedade que abandonou Deus porque abandonou os pobres. Além de Miquéias, que foi ferrenho opositor do progresso da cidade, pois este aconteceu às custas do sangue dos pobres. Carolina Maria de Jesus expressa ideia semelhante, ao escrever: "a cidade é um morcego que chupa o nosso sangue" (p. 159), referindo-se ao seu alto custo e sugerindo que o seu crescimento acontece por meio da exploração, principalmente dos mais pobres. Portanto, na pena da autora a atividade de poeta guarda semelhança com a de profeta precisamente na opção de ficar ao lado dos mais pobres e dos marginalizados da sociedade. 
Em outro momento, quando está "na cidade", Carolina Maria de Jesus relata suas impressões sobre o flagrante contraste entre a cidade e a favela.

Quando vou na cidade tenho a impressão que estou no paraizo. Acho sublime ver aquelas mulheres e crianças tão bem vestidas. Tão diferentes da favela. As casas com seus vasos de flores e cores variadas. Aquelas paisagens há de encantar os olhos dos visitantes de São Paulo, que ignoraram que a cidade mais afamada da America do Sul está enferma. Com suas ulceras. As favelas (JESUS, 2001, p. 76).

O destaque oferecido à beleza e à riqueza que podem ser encontradas na cidade são recursos linguísticos para intensificar o teor de denúncia feita à mais rica cidade sul-americana, que esconde sua mais grave e vergonhosa enfermidade, que é a miséria. Esta que empurrou muitas pessoas para uma vida de privações e precariedades. Portanto, o texto mais uma vez põe em relevo a ambiguidade do progresso e aproxima-se novamente dessa função profética de trazer à luz as mazelas da cidade, as suas contradições, sendo as favelas a maior delas.

Existem momentos que a narrativa revela que, além de cumprir uma função profética, também há instantes voltados à contemplação e ao desejo de transcender e até mesmo algumas considerações que se remetem mais diretamente à ideia de Deus. É surpreendente a capacidade que a autora tem de encontrar ocasião para reconstruir sentimentos de gozo com a beleza de coisas simples e escassas que ela podia ter na vida. Isso nos permite argumentar que há uma multiplicidade de interesses em Quarto de despejo e não apenas um único tema. Assim, não apenas a fome de pão, mas também podemos encontrar a fome de beleza. Apesar de todas as dificuldades, ela recria seus momentos de contemplação.

... Contemplava extasiada o céu cor de anil. E eu fiquei compreendendo que eu adoro o meu Brasil. O meu olhar posou nos arvoredos que existe no inicio da rua Pedro Vicente. As folhas movia-se. Pensei: elas estão aplaudindo este meu gesto de amor a minha Patria (JESUS, 2001, p. 32).

Esse momento de contemplação e êxtase não encobre a consciência de todas as dificuldades que enfrenta e que a leva a dizer, na mesma cena, o quanto a vida é amarga. Porém, ela insiste em voltar-se para a beleza e querer nela se perder, transcendendo a rotina de precariedade da sua vida. 
...Eu ando tão preocupada que ainda não contemplei os jardins da cidade. É epoca das flores brancas, a cor que predomina. É o mês de Maria e os altares deve estar adornados com flores brancas. Devemos agradecer Deus, ou a Natureza que nos deu as estrelas para adornar o céu, e as flores para adornar os prados e as várzeas e os bosques (JESUS, 2001, p. 32).

Ao voltar-se para contemplação da beleza que há no mundo, ela revela seu sentimento de profunda gratidão a Deus, à Natureza por toda a beleza oferecida e que ela pode contemplar. Essa capacidade de se maravilhar com as escassas coisas boas que a vida lhe oferece mostra-nos como Carolina Maria de Jesus consegue representar os fortes contrastes que fazem parte do mundo: as belezas do mundo e o horror das injustiças sociais que nele imperam.

Convém insistir em como a autora representa textualmente o contraste entre beleza natural e as injustiças provocadas pela política econômica vigente:

...o céu é belo, digno de contemplar porque as nuvens vagueiam e formam paisagens deslumbrantes. As brisas suaves perpassam conduzindo os perfumes das flores. E o astro rei sempre pontual para despontar-se e recluir-se. As aves percorrem o espaço demonstrando contentamento. A noite surge as estrelas cintilantes para adornar o céu azul. Há varias coisas belas no mundo que não é possivel descrever-se. Só uma coisa nos entristece: os preços, quando vamos fazer compras. Ofusca todas as belezas que existe (JESUS, 2001, p. 39).

A narrativa acentua fortemente a beleza do mundo, que pode ser ofuscada pelas precárias condições socioeconômicas em que a autora vive e inibir a capacidade para contemplar toda essa beleza e certamente assim ocorre com muitas pessoas que não conseguem voltar-se para as belas coisas diante de tanto sofrimento e precariedade material. Todavia, ela supera essa concepção de que diante da precariedade material grassa a insensibilidade estética e apresenta-nos um quadro de muita força expressiva quando justapõe elementos que se opõem. Dessa forma, sua fome por beleza não sucumbe diante da sua fome por pão e, por isso, em algumas ocasiões, ela cita que o céu azul é a homenagem da natureza às mães infelizes, assim como cita a matinal sinfonia de pardais e as nuvens que deslizam para o poente, tudo isso em meio às situações de precariedade de sua vida. Com isso, ela simboliza e antecipa uma vida de cores, beleza e tranquilidade que não tem.

É pela escrita que ela transcende sua condição de vida precária e molda criativamente uma outra condição qualitativamente melhor para sua própria existência. 
Enquanto escrevo vou pensando que resido num castelo cor de ouro que reluz na luz do sol. Que as janelas são de prata e as luzes de brilhantes. Que a minha vista circula no jardim e eu contemplo as flores de todas as qualidades. (...) É preciso criar este ambiente de fantasia, para esquecer que estou na favela. (p. 52).

Para Tillich (2009, p. 118), o absoluto se faz presente no encontro com a realidade e, segundo ele, "é isso que dá significado religioso ao elemento estilístico da subjetividade" e a perfeição pode ser "antecipada artisticamente". Antecipação, que é uma função da arte, "quer dizer ter e não ter". Significado equivalente ao da metáfora do Reino de Deus de "estar próximo" (TILLICH, 1992, p. 190). Ou seja, significa não possuir empiricamente, mas envolve a superação de uma determinada situação e, em sentido religioso, significa apropriar-se antecipadamente daquilo que se deseja. Ora, podemos argumentar que Carolina Maria de Jesus ao narrar que habita castelos reluzentes e com jardins repletos de belas e coloridas flores, transcende o sofrimento da vida presente com o poder que tem a arte de escrever e suspende o seu sofrimento, como se o pusesse entre parênteses, antecipando dias melhores em sua existência. Eis o poder de criar mundos, de transcender sua situação de precariedade, de antecipar um novo tempo.

Para finalizar, devemos destacar que em alguns momentos Quarto de despejo faz referências diretamente a ideia de Deus. Encontramos diversas alusões com expressões de agradecimentos e de uso cotidiano, como "graças a Deus", como hábito e expressões corriqueiras. Contudo, existem também momentos em que a narrativa expõe uma ideia de Deus que não apenas não é indiferente à situação de dor e precariedade da vida das pessoas pobres, como também mostra que está ao seu lado, em seu favor. Essa ideia aparece na cena em que narra a dificuldade sobre a falta de água na favela e o desejo de uma moradora vizinha à favela de que Deus enviasse uma enchente capaz de matar a todos os pobres favelados. A cena, que gerou a revolta das pessoas faveladas, é assim narrada por Carolina Maria de Jesus:

na enchente de 49 morreu o Pedro Cardoso, filho da Dona Ida. Quando eu soube que o Pedrinho havia morrido afogado pensei na decepção que teve a sua avó que pedia agua, agua, bastante agua para matar os favelados e veio agua e matou-lhe o neto. É para ela compreender que Deus é sóbrio. É o advogado dos humildes. Os pobres são criaturas de Deus. E o dinheiro é um metal criado e valorisado pelo homem. (...) Se Deus avisasse a Dona Ida que ela por não dar agua ia perder o seu filho para sempre, creio que ela estaria 
nos dando agua até hoje. O Pedro pagou em holocausto o orgulho de sua avó. E a maldade de sua mãe. É assim que Deus repreende (JESUS, 2001, p. 50).

Nesse caso, o ponto central a ser destacado é que a narrativa nos permite a reflexão teológica de que Deus não é indiferente ao sofrimento, à dor e às necessidades dos mais pobres. É significativo o uso da metáfora "Deus é sóbrio", pois Carolina Maria de Jesus em algumas oportunidades destaca os casos de abusos no uso do álcool e dos descontroles dele decorrente, assim evoca qualidades de moderação e equilíbrio. A outra metáfora, “advogado dos humildes", não apenas não vai relacionar a pobreza e todas dificuldades associadas a ela como consequência de uma ação ou ira divina, como vai reivindicar que Deus é quem está na defesa da causa dos pobres. A ideia de que Deus criou as pessoas pobres, longe de significar que Deus criou a pobreza, confere a elas a dignidade de serem suas criações. Essa ideia ganha mais clareza e força através da justaposição dos aspectos opositivos, quando a narrativa sublinha que o dinheiro é criação humana. Logo, as desigualdades sociais e seus reflexos, como as favelas e a fome, não apenas não são criações de Deus como os pobres são acolhidos e defendidos por ele.

Em outro momento, a autora narra um sonho, cuja interpretação ela mesma oferece: foi enviado por Deus.

...Eu durmi. E tive um sonho maravilhoso. Sonhei que eu era um anjo. Meu vestido era amplo. Mangas longas cor de rosa. Eu ia da terra para o céu. E pegava as estrelas na mão para contemplá-las. Conversar com as estrelas. Elas organisaram um espetáculo para homenagear-me. Dançavam ao meu redor e formavam um risco luminoso.

Quando despertei pensei: eu sou tão pobre. Não posso ir num espetaculo, por isso Deus envia-me estes sonhos deslumbrantes para minh'alma dolorida. Ao Deus que me proteje, envio os meus agradecimentos (JESUS, 2001, p. 107).

O sonho revela que suas necessidades vão além de comida e dinheiro, pois manifesta que a fome também é por beleza e arte. Ou seja, expressa o desejo de viver a plenitude da sua existência, que não se encerra na dura rotina de trabalho na luta para sua sobrevivência numa sociedade industrial. Ao sonhar que era um anjo, que contemplava e tocava as estrelas e era espectadora de um lindo espetáculo de dança organizado em sua homenagem, mais uma vez ela reconstrói artisticamente a antecipação dessa vida que ainda não tem. Nessa reconstrução textual, ela mesma oferece a interpretação de que Deus foi quem 
lhe enviou o sonho. Com isso, oferece-nos a oportunidade para a reflexão teológica sobre um conceito de Deus que tem profundo interesse em ver o ser humano para além da insignificância da sociedade industrial, que o reduz a objeto de uma engrenagem em meio a tantos outros objetos.

Assim, ao despertar do sonho ela ratifica sua condição de pobreza e consequentemente a consciência de que numa sociedade capitalista, que acentua as desigualdades, ela não teria possibilidade de frequentar as plateias das salas de espetáculos da cidade. Ao referir-se a Deus como aquele que enviou o sonho por ela descrito, a fim de aliviar a dor da sua alma, ela revelanos textualmente um Deus misericordioso, cujo cuidado não se restringe somente em restaurar a força do corpo para voltar ao trabalho, mas tratar com arte e beleza a alma dolorida.

\section{Considerações finais}

Ao longo desse percurso procuramos destacar a sensibilidade artística de Carolina Maria de Jesus em narrar-se a si mesma pela voz literária. Quarto de despejo apresenta-se como um pacto identitário entre a autora, a personagem e a narradora e, inspirados na compreensão ambígua de religião e das formas culturais, podemos dizer que a narrativa nos oferece a possibilidade de compreensão da complexidade do texto e da própria vida. Há uma lacuna nos estudos que interpretam esse texto da autora, pois as interpretações que prevaleceram na época em que o livro foi lançado enfatizaram o caráter documental do texto a respeito da fome no Brasil dos anos 1950. Porém, Quarto de despejo não pode deixar de ser visto fora da dimensão literária porque resulta da habilidade da autora em criar sofisticadas representações do seu dia a dia marcado pela miséria.

A compreensão da religião como preocupação suprema oferece a oportunidade de pensá-la para além dos aspectos religiosos institucionais. Essa compreensão existencial da religião é que possibilita percebê-la em todos os âmbitos, pois significa o estado em que se pode ser tomado pela preocupação suprema, que não se limita a espaço e nem a determinados momentos da vida. Nesse sentido, tivemos esse ponto de partida para compreensão da narrativa de Carolina Maria de Jesus, que enfrenta textualmente os impactos negativos produzidos pelo processo de industrialização naquele período, assumindo artisticamente sua vida de extrema precarização.

O conceito de demônico possibilita a compreensão do aspecto religioso e das formas culturais pelo seu lado negativo. Nesse sentido, o conceito 
tillichiano é portador de significativo potencial interpretativo na análise de manifestações culturais em geral e do texto literário em particular, embora Tillich tenha dado preferência a outras manifestações artísticas. Pessoas como Carolina Maria de Jesus não conseguiam emprego e nem acesso a condições mínimas para uma vida digna, pois eram massacradas por uma política econômica assentada em uma "estrutura do mal", conforme a linguagem tillichiana, que não era capaz de mudar a vida de pessoas como ela. Ao narrar as experiências vividas entre os anos 1955 e 1959, refere-se a um período de grande efervescência econômica, de industrialização, de modernização e, com isso, expõe as profundas e dolorosas contradições desse período. Pensando na ambiguidade da religião e das diferentes formas culturais, devemos admitir que aí está uma das afirmações mais significativas e uma das mais importantes contribuições do próprio Tillich. Com tudo isso, a própria religião ainda reivindica ser resposta para as ambiguidades da vida, como paradoxalmente apresentou-se no texto da nossa autora.

Convém salientar ainda que a obra Quarto de despejo, não se encerra nas considerações articuladas neste texto, que buscou identificar o modo como a autora compreende o mundo, a si mesma, os dramas da existência, suas relações sociais, sua visão política e econômica, como ela lidava com a necessidade de produção de sentido na arte, notadamente na literatura, tendo nela um meio de transcendência. Dessa forma, podemos perceber que o texto interage com o sagrado, mesmo sendo pelo "seu lado negativo" ou quando ele não é nomeado pela autora. Como afirmamos, os interesses e assuntos elencados na obra são diversificados, mostrando a complexidade da autora/personagem/narradora e da própria vida. Assim, ao elegermos a dimensão religiosa como aspecto central para a compreensão da obra, longe de reduzi-la ao âmbito dos estudos da religião em geral e da teologia especificamente, propomos novas chaves hermenêuticas para o texto. Portanto, não negligenciamos o fato de que o texto se oferece a muitas abordagens e interpretações, assim como o próprio fenômeno religioso.

\section{Referências}

ALMEIDA, Paulo Roberto de. As relações econômicas internacionais do Brasil dos anos 1950 aos 80. Revista Brasileira de Política Internacional, v. 50, n. 2: p. 60-79, jul./dec. 2007. Acesso em 20/09/2020. 
ARRUDA, Maria Arminda do Nascimento. Empreendedores culturais imigrantes em São Paulo de 1950. Tempo Social, revista de sociologia da USP, v. 17, n. 1, p. 135-158, 2005. Acesso em 20/09/2020.

BONORA, Antonio. Amós, o profeta da justiça. São Paulo: Paulinas, 1983.

CALVANI, Carlos Eduardo Brandão. Teologia e MPB. São Paulo: Loyola, 1998.

CANDIDO, Antonio. O direito à literatura. Revista Prosa Verso e Arte. https://www. revistaprosaversoearte.com/o-direito-a-literatura-antonio-candido/,1995. Acesso em $01 / 09 / 2020$.

CAPUTO, Ana Claudia; MELO, Hildete Pereira de. A Industrialização Brasileira nos Anos de 1950: Uma Análise da Instrução 113 da SUMOC. In.: Estudos Econômicos. São Paulo, vol. 39, n. 3, p. 513-538, set./jul., 2009.

CORONEL, Luciana Paiva. A censura ao direito de sonhar em. Quarto de despejo, de Carolina Maria de Jesus. Estudos de literatura brasileira contemporânea, n. 44, p. 271-288, jul./ dez. 2014.

EAGLETON, Terry. A ideia de cultura. 2. ed. São Paulo: Editora Unesp, 2011.

HIGUET, A. Etienne. As relações entre religião e cultura no pensamento de Paul Tillich. Revista Eletrônica Correlatio, v. 7 n ${ }^{\circ}$ 14, - Dezembro/ 2008.

HIGUET, Etienne Alfred. Atualidade da teologia da cultura de Paul Tillich. Revista Eletrônica Correlatio, v. 18, n. 2, p. 11-25 - Dezembro de 2019.

JESUS, Carolina Maria de. Quarto de despejo. Diário de uma favelada. 8. ed. São Paulo: Ática, 2001.

JESUS, Carolina Maria de. Quarto de despejo: diário de uma favelada. 10 ed. São Paulo: Ática, 2014.

LEJEUNE, Philippe. O pacto autobiográfico: de Rousseau à internet. Jovita Maria Gerheim Noronha (ORG.). Belo Horizonte: Editora UFMG, 2008.

NEVES, Juliana. Campo da cultura e mecenato artístico na cidade de São Paulo: a imprensa e os museus de arte no segundo pós-guerra, p. 39-55. In.: BUENO, Maria Lucia (org.). Sociologia das artes visuais no Brasil. São Paulo: Editora SENAC São Paulo, 2012.

OLIVEIRA, Francisco de. O jeitinho e o jeitão. 2012. Disponível em: chrome-extension:// oemmndcbldboiebfnladdacbdfmadadm/https://edisciplinas.usp.br/pluginfile.php/4422184/ mod_resource/content/1/Francisco $\% 20$ de $\% 20$ Oliveira $\% 20$ - $\% 20$ Jeitinho $\% 20$ e $\% 20$ jeit\%C3\%A3o.pdf. Acesso em 10/09/2020.

SICRE, Jose Luis. Profetismo em Israel: o profeta: os profetas: a mensagem. Petrópolis: Vozes, 1998.

TILLICH, Paul. Teologia da cultura. São Paulo: Fonte Editorial, 2009.

TILLICH, Paul. A Era Protestante. São Bernardo do Campo: Instituto Ecumênico de PósGraduação em Ciências da Religião, 1992.

TILLICH, Paul. Teologia Sistemática. 2. ed. São Leopoldo: Sinodal, 1987. 
TILLICH, Paul. A coragem de ser: baseado nas Conferências Terry, pronunciadas na Yale University. 3. ed. Rio de Janeiro: Paz e Terra, 1976.

TILLICH, Paul. Filosofía de la Relgión. Buenos Aires : Editorial La Aurora, 1973.

Submetido em: 12-10-2020

Aceito em: 26-11-2020 